\title{
Clustering Educational Categories in a heterogeneous Labour Market
}

Citation for published version (APA):

Heijke, J. A. M., Matheeuwsen, A., \& Willems, E. (2003). Clustering Educational Categories in a heterogeneous Labour Market. Education Economics, 11(1), 89-108.

https://doi.org/10.1080/09645290210127543

Document status and date:

Published: 01/01/2003

DOI:

10.1080/09645290210127543

Document Version:

Publisher's PDF, also known as Version of record

\section{Please check the document version of this publication:}

- A submitted manuscript is the version of the article upon submission and before peer-review. There can be important differences between the submitted version and the official published version of record.

People interested in the research are advised to contact the author for the final version of the publication, or visit the DOI to the publisher's website.

- The final author version and the galley proof are versions of the publication after peer review.

- The final published version features the final layout of the paper including the volume, issue and page numbers.

Link to publication

\footnotetext{
General rights rights.

- You may freely distribute the URL identifying the publication in the public portal. please follow below link for the End User Agreement:

www.umlib.nl/taverne-license

Take down policy

If you believe that this document breaches copyright please contact us at:

repository@maastrichtuniversity.nl

providing details and we will investigate your claim.
}

Copyright and moral rights for the publications made accessible in the public portal are retained by the authors and/or other copyright owners and it is a condition of accessing publications that users recognise and abide by the legal requirements associated with these

- Users may download and print one copy of any publication from the public portal for the purpose of private study or research.

- You may not further distribute the material or use it for any profit-making activity or commercial gain

If the publication is distributed under the terms of Article $25 \mathrm{fa}$ of the Dutch Copyright Act, indicated by the "Taverne" license above, 


\title{
Clustering Educational Categories in a Heterogeneous Labour Market
}

\author{
HANS HEIJKE, ASTRID MATHEEUWSEN \& ED WILLEMS
}

\begin{abstract}
In most countries, the systems of educational classification are based on administrative criteria. For analyses of the labour-market position of educational categories, however, a classification that demarcates an individual's competencies obtained by the courses attended is a better alternative. In the present paper, we will analyse the substitution processes in the labour market in order to develop an educational classification that is based on the observed possibilities of workers with different educational backgrounds to enter similar occupations. As an additional criterion, we use the recognizability of the groups distinguished. In addition, we incorporate the criterion of statistical reliability. This results in an educational classification with 113 distinct categories.
\end{abstract}

\section{Introduction}

In most countries, the systems of educational classification are solely based on administrative criteria. ${ }^{1}$ The International Standard Classification of Education (ISCED) has such a background too. This classification, which constitutes the basis for many national classifications, distinguishes several formal levels of education and fields of study. The purpose of standard educational classifications is to reflect the formal structure of the educational system. They do not, however, indicate the real differences in competencies that people have obtained during their education in order to fulfil their jobs in the labour market.

If one's objective is to give a detailed overview of all prevailing kinds of education, an administrative classification can be very useful. For most labourmarket research, however, the strict demarcation of educational types seems inappropriate. It ignores the segmented structure of the labour market. On the one hand, there are labour-market segments with very strict educational requirements (craft markets; Doeringer \& Piore, 1971), sometimes regulated by law. Examples are the requirements for doctors, lawyers, accountants, etc. On the other hand, a large degree of educational flexibility can be observed in many segments of the labour market and there is no one-to-one relationship between education and labour-market status (see, for example, Sheldon, 1985; de Grip \& Heijke, 1988).

H. Heijke, A Matheeuwsen \& E Willems, Research Centre for Education and the Labour Market, Maastricht University, P.O. Box 616, 6200 MD, Maastricht, The Netherlands. E-mail: h.heijke@roa.unimaas.nl 
The overall aim of the present paper is to design an educational classification that is suitable for applied research on the labour-market position of types of education. More in particular, the classification that we intend to develop should be suitable for manpower forecasting. In the traditional approach to manpower forecasting, the first step is to determine future demand for labour with a particular educational background on the basis of desired medium-term economic growth. This demand is then set off against the expected supply with the same educational background, as can be deduced from the developments in the working population and the outflow from education (Parnes, 1962). The calculated future discrepancies between supply and demand, according to the proponents of this approach, indicate to what degree the educational facilities concerned should be adapted in order to be able to achieve the desired economic growth. To calculate these discrepancies, it is of course necessary that the differentiation of the demand side of the labour market that is used, often in terms of occupations, closely matches the differentiation of the supply side in terms of education programmes. These differentiations should match as closely as possible the existing segmentation in the labour market. It is therefore not surprising that, during the initial stages of the development of the manpower forecasting approach, Parnes pointed out the importance of a good classification system for manpower forecasting studies.

Over the years, the aim of manpower forecasting has shifted from a planning approach, in which the calculated future labour-market discrepancies indicate which investments in education should take place in order to prevent these discrepancies, towards a transparency approach, in which the forecasted discrepancies only try to give indications to the market parties of the labour-market perspectives of education programmes (see van Eijs, 1993, 1994). Today, manpower forecasts aim to provide useful information for; (i) policy-makers, who may use it to adapt the educational system, (ii) vocational guidance for those who making educational choices; and (iii) employers for their recruitment policies with respect to the type of employees that could fill future vacancies. Not only the aim of the manpower forecasting method has changed over the years, but the method itself has also been greatly improved. The aforementioned, slightly mechanical forecasting method was replaced by the use of labour-market models that more closely reflect the functioning of the labour market (see, for example, Heijke, 1994). However, good classifications that take into account the actual labour-market structure are still relevant. From this viewpoint, de Grip et al. (1991) developed an occupational classification that was based on the educational structure of the work force within occupations. The Standard Occupational Classification 1992 of Statistics Netherlands (CBS, 1993) also takes the educational requirements as the starting point.

As already stated, it may be clear that to model the labour-market developments by educational category, it is useful to use an educational classification that takes into account the actual segmentation of the labour market. It should be pointed out that we wish to focus on the competencies that people acquire through education and the effects of these competencies on their functioning in the labour market. To do so, we use the criterion of the actual substitution possibilities on the labour market, because these indicate to which extent workers with a different educational background can be employed in various occupations. These substitution possibilities implicitly indicate the overlapping skills of workers that have completed different courses. In other words, we want to take into account the substitution border lines that separate the various educational types on the labour market. This implies that the possibility of substitution is the basic criterion for developing an 
educational classification. In this view, substitution can be defined as the extent to which individuals with different educational backgrounds compete for the same type of jobs (occupations).

To develop a labour-market-related educational classification, we will use a clustering technique. The starting point of this cluster analysis will be the very detailed, five-digit Dutch educational classification based on ISCED Standard Onderwijs Indeling (SOI). At this aggregation level, approximately 800 educational types are distinguished. We will examine the substitution possibilities between occupational categories. The most detailed level available from the data is the three-digit level according to International Standard Classifications of Occupations (ISCO) 1968. At this level, approximately 320 occupations are distinguished. On the basis of the aforementioned substitution criterion, we intend to derive a classification that distinguishes approximately 100 educational categories, which seems to be a reasonable level of aggregation for both vocational guidance and most policy issues.

Besides the basic criterion of the actual demarcation lines of the labour market, we must include some additional criteria. First, the aggregation level that we implement should not be too detailed, as this implies a lower statistical reliability. Hence, we take a minimum cell content of 5000 workers for each educational category distinguished. Second, the educational classification should be recognizable for its users, such as policy-makers, career counsellors, employers and individual students. Educational categories that cover various formal levels, for instance, will not be practicable for most users.

The remainder of the present paper is organized as follows. In the next section, we discuss the primary clustering criterion (i.e., substitution in the labour market). The third section provides more insight into the data and the starting point for the clustering process, and the following section discusses the results of the cluster analyses. In the fifth section, we discuss in detail the structure of the final classification, which we round up with the conclusion. Finally, the entire classification and its relation with the SOI is presented in the Appendix.

\section{Substitution in the Labour Market}

As we pointed out in the Introduction, the labour market has a heterogeneous structure, in the sense that individuals obtain different competencies and therefore have different productivity levels in the labour market. According to human capital theory (see, for example, Schultz, 1961; Becker, 1962), individuals invest in 'human capital' by taking education or by obtaining experience (on-thejob training). By achieving a higher level of education or becoming more experienced, they can enhance their productivity and increase their income. More institutionalized theories, such as the labour queue theory of Thurow (1975), argue that employers select workers according to the expected training costs. Individuals with the lowest costs are placed at the head of the so-called labour queue and are therefore selected first. An individual's productivity is determined completely by the job he/she has.

The theory of job matching can be located somewhere between the two extremes of human capital theory and labour queue theory (see, for example, Jovanovic, 1979; Hartog, 1992; van Eijs \& Heijke, 2000). The theory of job matching states that the productivity of individuals is neither determined completely by their jobs (labour queue) nor fully determined by their personal abilities, such as their 
educational background (human capital). This implies that some people (or, in our context, types of education) have a comparative advantage in the one job (occupation), whereas others have a comparative advantage in another job.

We assume that workers compete, according to their comparative advantages, for jobs with certain occupational requirements mainly on the basis of their educational background. ${ }^{2}$ This relation between occupation and education is situated somewhere between the extremes of perfect competition on the one hand, and a completely segmented one-to-one labour market on the other. In other words, some educational types focus entirely on one or a limited number of occupations, whereas others can be used in many labour-market areas.

Several studies have shown the flexibility of the various types of education by means of the Gini-Hirschman dispersion index (see, for example, Sheldon, 1985; de Grip \& Heijke, 1988; van derVelden \& Willems, 1994; Borghans \& Heijke, 1998):

$$
G H_{i}=\left[1-\sum_{j}\left(\frac{p_{i, j}}{\sum_{j} p_{i, j}}\right)^{2}\right] \frac{I}{I-1}
$$

where $G H_{i}$ is the Gini-Hirschman dispersion index for educational category $i, p_{i, j}$ is the number of workers with educational background $i$ in occupation $j$, and $I$ is the total number of educational categories distinguished.

This Gini-Hirschman index represents the realised (ex post) switching possibilities of working persons with a specific educational background to other occupational classes. ${ }^{3}$ The index is equal to 1 if and only if the workers with the educational background concerned are equally distributed across all occupations distinguished. If a type of education focuses on only one occupation, then the GiniHirshman index is equal to 0 .

The Gini-Hirschman only indicates the occupational dispersion of the educational types. It does not provide information about other categories of workers (with different educational backgrounds) that may compete for the same occupations in the labour market. Borghans (1992) and van der Velden and Borghans (1993) have introduced the similarity or competition index, which does provide information about the apparent substitution possibilities in the labour market. This similarity index s is defined as:

$$
S_{i, i^{\prime}}=\frac{\sum_{j}\left(\frac{p_{i, j}}{\sum_{j} p_{i, j}}\right)\left(\frac{p_{i^{\prime}, j}}{\sum_{j} p_{i^{\prime}, j}}\right)}{\sqrt{\sum_{j}\left(\frac{p_{i, j}}{\sum_{j} p_{i, j}}\right)^{2} \sum_{j}\left(\frac{p_{i^{\prime}, j}}{\sum_{j} p_{i^{\prime}, j}}\right)^{2}}}
$$

where $S_{i, i^{\prime}}$ is the similarity index of educational category $i$ with educational category $i^{\prime}$.

This similarity index $S_{i, i^{\prime}}$ is equal to 0 (no similarity) if the two types of education $i$ and $i^{\prime}$ have no overlapping occupations. It is equal to 1 (perfect similarity) if and only if the occupational structure of both educational types is completely equal in the sense that the relative numbers of workers in each occupation is equal for these two educational types. If in total $I$ number of educational types are distinguished, an $I \times I$ matrix $\boldsymbol{S}$ of similarity indexes can be specified. Obviously the similarity of a type of education with itself $\left(S_{i, i}\right)$ is equal to 1 and the similarity index is symmetric $\left(S_{i, i^{\prime}}=S_{i^{\prime}, i}\right)$. This implies that we can distinguish $I(I-1) / 2$ similarity indexes. 


\section{Cluster Analysis}

The similarity criterion specified in equation (2) is often used in cluster analyses. ${ }^{4}$ Clustering takes place on the basis of the highest similarity index in matrix $\boldsymbol{S}$. Usually a hierarchical technique is adopted, in which in each iteration one (already clustered) educational category is combined with only one other (already clustered) category. If, for example, education $i$ and education $i^{\prime}$ have the highest similarity $S_{i, i^{\prime}}$ of all combinations, $i$ and $i^{\prime}$ together will form the new educational cluster.

After each iteration in the clustering process, we must derive the similarity index of the new cluster, say $k=i+i^{\prime}$, with all other educational categories. The clustering literature distinguishes six methods: single linkage, complete linkage, average linkage, centroid clustering, medium method, and minimal variance or Ward's method. All these methods state that the similarity between the new cluster $k$ and another educational category $k^{\prime}\left(S_{k, k^{\prime}}\right)$ is the weighted average of $S_{k^{\prime}, i}, S_{k^{\prime}, i^{\prime}}$, and $S_{i, i^{\prime}}$ (see Lorr, 1983). The weight coefficients vary over the six methods distinguished (for a discussion of the advantages and disadvantages of these methods, see de Grip et al. (1987).

Although the aforementioned methods for the calculation of new similarities between the newly formed educational clusters have obvious computational advantages, we will opt for a different - in our view, less biased-technique. After every iteration in the clustering process, we re-calculate similarity matrix $\boldsymbol{S}$ according to equation (2). This matrix will only be modified for the similarity indexes with the new clustered educational category. We can specify two reasons for this procedure. First, the standard clustering algorithms ignore the fact that the original entities (types of education) have different sizes and thus ignore the impact on the combined similarity with other types of education. Second, and partly related to this, these techniques ignore the fact that the starting point of the cluster analysis is already a clustering of educational categories.

In summary, the cluster analysis procedure can be described as follows:

1. Calculate similarity matrix $\boldsymbol{S}$, which contains the similarity index $S_{i, i^{\prime}}$ for all educational categories initially distinguished.

2. Combine the two educational categories that have the highest mutual similarity.

3. Return to step 1.

Without additional restrictions, this process will continue until only one cluster is left. Stopping rules that are generally implemented are (1) the number of categories that will eventually be distinguished, or (2) a minimum similarity required for clustering. We opt for the latter and will stop the clustering process if the largest similarity between two educational categories is smaller than 0.5 .

\section{Data}

The data set on which the cluster analysis described in the previous section will be applied is the Labour Force Survey ('Enquête Beroepsbevolking' (EBB)) 1992 and $1994^{5}$ of Statistics Netherlands. The EBB is a continuous survey of Dutch households, focusing on the labour-market situation of the labour force. Information collected includes employment status (employed, unemployed, etc.), educational background, sex, age and, for those who are employed, the sector of industry, 


\section{Hans Heijke et al.}

occupation, and number of hours worked. The annual sample size is approximately $1 \%$, corresponding to about 120000 individuals.

For our purpose, we subtracted from the EBB the matrix of the number of workers per educational category by occupational group on the most detailed level available. For the educational categories, this implies the five-digit SOI classification, while the occupational groups refer to the three-digit format of ISCO $1968 .^{6}$ At these levels of aggregation, more than 800 educational categories ${ }^{7}$ and 320 occupational groups are distinguished. This data matrix will constitute the starting point of the cluster analysis.

To provide a better view of the data matrix used, we will first present the number of educational types distinguished per (formal) level of education in Table 1. This table also gives an overview of the average number of workers in each category. Most educational categories refer to the level of intermediate vocational education (IVE). At the two levels of higher education (higher vocational education (HVE) and university education (UE)), however, we also distinguish many categories, with on average only 2500-4500 workers. By definition, at the lowest level (primary education), only one type of education is distinguished.

Subsequently, Figure 1 presents the number of educational categories by number of Workers in each category. It appears that at this low aggregation level of educational specialization, the majority of the categories represent fewer than 2500 workers: over 500 of the 800 types of education belong to this group. Within this group, the educational categories with fewer than 500 workers are over-represented. Only 15 of the five-digit educational categories have more than 40000 workers.

The large over-representation of very small categories in the five-digit SOI has the disadvantage that the reliability of these figures is very low. ${ }^{8}$ This implies that the division over the occupational groups, and therefore also the values of the similarity index, are statistically unreliable for these small educational categories. To overcome these disadvantages, we have caried out a first grouping of educational categories to ensure that groups of at least 2500 workers are distinguished.

Table 1. Number of educational categories (five-digit SOI) distinguished and average number of workers in each category by level of education, average of 1992 and 1994

\begin{tabular}{lcc}
\hline Level of education & $\begin{array}{c}\text { Number of } \\
\text { categories }\end{array}$ & $\begin{array}{c}\text { Average number } \\
\text { of workers } \\
\text { per category }\end{array}$ \\
\hline Primary education & 1 & 531500 \\
LGSE/PVE & 130 & 10500 \\
HGSE/PUE/IVE & 310 & 8000 \\
HVE & 225 & 4500 \\
UE & 177 & 2500 \\
Total (including rest) & 844 & 7000 \\
\hline
\end{tabular}

Source: CBS/Research Centre for Education and the Labour Market.

Note: All educational levels in Table 1 are defined as the following: PVE (Preparatory Vocational Education), LGSE (Lower General Secondary Education), HGSE (Higher General Secondary Education), IVE (Intermediate Vocational Education), HVE (Higher Vocational Education), and UE (University Education), PUE (Pre-university Education). 


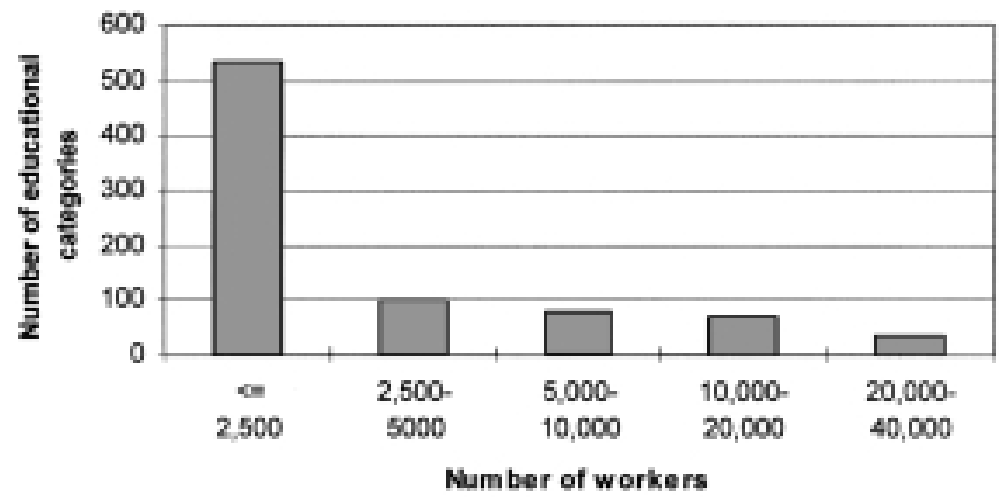

Fig. 1. Number of educational categories (five-digit SOI) by class of number of workers in each category, average of 1992 and 1994.

This grouping is based on the highest similarities within the same four-digit SOI. That is to say, if an educational type at the five-digit level has fewer than 2500 workers, then it is clustered with the educational category within the same four-digit category or categories for which the mutual similarity index is highest. After this pre-clustering of the data, we distinguish fewer than 400 educational categories as a starting point for the analyses. ${ }^{9}$ It may be expected that the advantages of this grouping of small categories outweigh the disadvantages of using very small categories in the cluster analysis.

\section{Results}

\section{Free Clustering of 1994 Data}

On the basis of the adjusted data set of EBB 1994, distinguishing 361 educational categories and 330 occupational groups, we carried out the cluster analysis according to the method described in the second section. As a stopping criterion for clustering, we specified a minimum similarity of 0.5 . This means that educational categories were clustered as long as there was a similar educational category (or cluster of categories) with a mutual similarity of over 0.5 .

In this analysis, 103 educational clusters are distinguished. It appears that we can distinguish a large diversity of educational clusters. Some clusters consist of more than $5 \%$ or $10 \%$ of all categories distinguished, which implies over 40 fivedigit categories. On the contrary, many categories consist of only one or a few categories. The picture is even more skewed if we look at the number of workers in each cluster. The largest cluster represents almost 1.8 million workers, representing approximately $30 \%$ of the total working population. In this category, all levels of general secondary education are taken together. For purposes of vocational guidance and policy evaluation, such a skewed categorization of educational categories is not suitable.

Probably the most striking result of this first cluster analysis is that much of the substitution between educational categories is not restricted to one educational level. Especially, the preparatory vocational education (PVE) and IVE levels are frequent competitors. Table 2 shows that one-half of the educational clusters distinguished refer to only one formal level of education. Most of the overlapping 
Table 2. Number of educational levels combined in one educational cluster; unrestricted cluster analysis, 1994

\begin{tabular}{lc}
\hline & $\begin{array}{c}\text { Number of } \\
\text { educational } \\
\text { clusters }\end{array}$ \\
\hline One level & 53 \\
LGSE/PVE & 5 \\
HGSE/PUE/IVE & 26 \\
HVE & 14 \\
UE & 8 \\
Two levels & 35 \\
LGSE/PVE and HGSE/PUE/IVE & 16 \\
HGSE/PUE/IVE and HVE & 10 \\
HVE and UE & 9 \\
Three levels & 11 \\
Primary education and LGSE/PVE and HGSE/PUE/IVE & 1 \\
LGSE/PVE and HGSE/PUE/IVE and HVE & 2 \\
HGSE/PUE/IVE and HVE and UE & 8 \\
\hline
\end{tabular}

educational levels in one cluster refer to the PVE and IVE levels on the one hand, and the HVE and UE levels on the other.

In Figure 2, the resulting educational clusters are classified according to the modal educational level of the cluster. ${ }^{10}$ For each of the five levels, the distribution of the real educational level of the workers within such a category is given. As can easily be seen for the category with a modal educational level of lower general secondary education/preparatory vocational education (LGSE)/PVE (the second bar), about $30 \%$ of the labour-market substitution refers to IVE-educated workers. Furthermore, competition takes place between IVE workers and workers with an educational background at HVE or even university level. Substitution between workers of $\mathrm{HVE}$ and university level also appears to be frequent. About $25 \%$ of the UE domain in the labour market is occupied by workers with a HVE background.

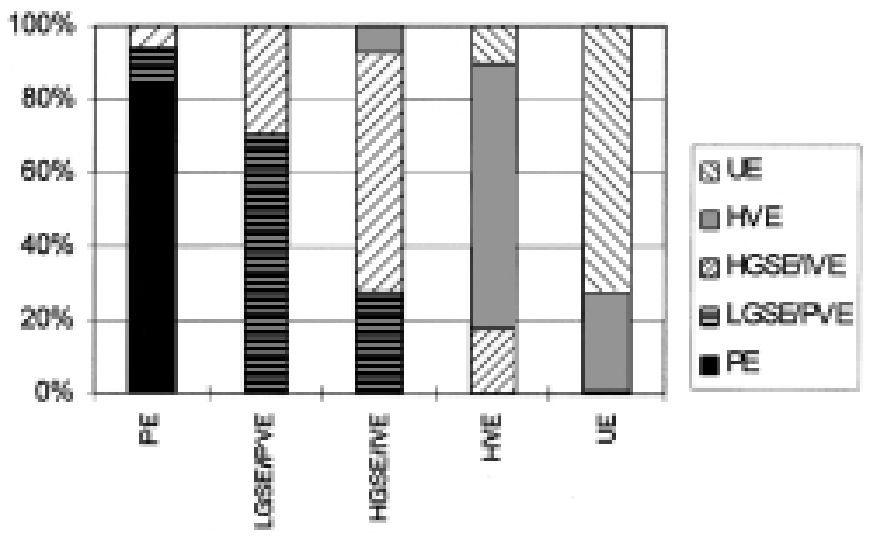

Fig. 2. Distribution of educational levels by modal educational level of the clusters. 
Conversely, $10 \%$ of the educational clusters with HVE as the modal refers to workers with a university degree.

We must, however, apply some nuances to these results. First, as pointed out earlier, the IVE level in the Dutch educational system, and therefore also in the SOI, is very heterogeneous. Three formal educational levels are grouped in this category: 'regular' IVE (usually 4 years of education), 'short' IVE (usually 2 years), and apprenticeships. This means that there is sometimes only a slight difference between the PVE and IVE level. Furthermore, the educational classification only registers the formal training courses. The increase of a worker's human capital due to informal on-the-job training and work experience is not reflected in the data. This implies that there may be two distinct groups within each occupation. An older group of workers with an educational background at PVE level and (unobserved) informal training and work experience, and a younger group with an IVE background. These 'inter'-generational differences, however, cannot be seen as real 'intra'-generational substitution possibilities between PVE-and IVE-educated workers.

Related to this phenomenon is the unobserved heterogeneity within the occupational categories distinguished. Jobs can be upgraded because of technological or organizational developments. As the data does not distinguish between the upgraded jobs and the jobs within an occupational group that are not upgraded, the observed substitution possibilities between workers of different educational levels will not indicate the real possibilities of employers to hire workers with different educational backgrounds for the same jobs.

The aforementioned developments may coincide: work experience or on-the-job training increases the competencies of workers, as a result of which the job that they occupy can be upgraded. It is also possible, however, that the experienced worker switches to a job with higher requirements. For this latter job the employer has two options: the experienced, but formally lower-educated, worker; or a young, formally higher-educated, person.

\section{Clustering by Age Category of 1994 Data}

To overcome the drawback that the observed substitution possibilities are the result of heterogeneity of worker competencies within an educational category, we have restricted the analysis to the younger age groups (i.e., those between 15 and 29 years of age). These workers have hardly any working experience and are therefore better comparable on the basis of their educational background as an indicator of their knowledge. In general, the results of this cluster analysis seem similar to the results of the cluster analysis already described with respect to the total working population. We now distinguish 137 educational clusters. The assumption made earlier (that substitution on the labour market between several educational levels is mainly the result of the fact that lower-educated people with relatively much work experience and informal in-the-job training compete with younger higher-educated workers for the same jobs) does not hold. Again, we see many educational clusters in which two or more educational levels are represented. Table 3 shows that one educational cluster contains all five levels distinguished. On the contrary, more than $60 \%$ of the cluster refers to only one level. Remarkably one cluster refers to the primary (LGSE/PVE) and tertiary (HVE) level. This is HVE library and documentation together with economic specialization within PVE, not a very plausible result. 
Table 3. Number of educational levels combined in one educational cluster; cluster analysis only for the younger age groups, 1994

\begin{tabular}{lc}
\hline & $\begin{array}{c}\text { Number of } \\
\text { educational } \\
\text { clusters }\end{array}$ \\
Educational level & 85 \\
\hline One level & 7 \\
LGSE/PVE & 27 \\
HGSE/PUE/IVE & 30 \\
HVE & 21 \\
UE & \\
Two levels & 38 \\
LGSE/PVE and HGSE/PUE/IVE & 1 \\
LGSE/PVE and HVE & 11 \\
HGSE/PUE/IVE and HVE & 10 \\
HVE and UE & 13 \\
Three levels & 9 \\
LGSE/PVE and HGSE/PUE/IVE and HVE & 4 \\
HGSE/PUE/IVE and HVE and UE & 1 \\
Five levels & 1 \\
Primary education and LGSE/PVE and HGSE/PUE/IVE & \\
and HVE and UE & \\
\hline
\end{tabular}

\section{Evaluation: Clustering by Level of Education}

The existence of different educational levels within an education cluster is unsatisfactory, both for theoretical and for practical reasons. Our theoretical principle was that a certain education programme gives graduates a comparative advantage in certain types of jobs. Individuals who continue their educational careers by means of a study at a higher level, invest an additional $4-5$ years in their human capital. This should give them the prospect of having a comparative advantage in jobs at a higher level. As a result of instability in sub-markets of the labour market and the effects of institutional factors, however, the allocation of graduates may deviate from what would be optimal from a comparative point of view. After completing a higher education, it may therefore be possible that the situation in the labour market is such that one is forced to temporarily accept a job at a lower level. ${ }^{11}$

Overlap between educational levels within a single occupation need not always be a sign of misallocation. As stated earlier, there may be heterogeneity within occupations with respect to the level at which workers function. The higher educated, for example, may be working in a part of the occupational group that is subject to the process of upgrading as a result of technological and organizational developments, or may be able to perform much better at a particular job level than their less educated colleagues. ${ }^{12}$

For these reasons, we believe that the results of the cluster analyses presented cannot be used to create an educational classification. An educational cluster that refers to several and diverse formal levels of education will therefore prove impractical: for justifiable reasons, policy evaluations usually distinguish between 
Table 4. Number of educational clusters

distinguished per cluster analysis

\begin{tabular}{lcc}
\hline Data year & $\begin{array}{c}\text { Age group } \\
\text { (years) }\end{array}$ & $\begin{array}{c}\text { Number of } \\
\text { educational } \\
\text { clusters }\end{array}$ \\
\hline 1994 & $15-64$ & 163 \\
1994 & $15-29$ & 197 \\
1992 & $15-64$ & 177 \\
1992 and 1994 & $15-64$ & 155 \\
\hline
\end{tabular}

similar educational levels, and students also make their study choices within such similar levels. To overcome this drawback and with a view to the recognizability criterion outlined in the Introduction, we restrict the cluster analysis in such a way that only educational categories within the same level can be combined. ${ }^{13}$ In this analysis, we distinguish seven main categories, rather than the five formal levels distinguished in the SOI. We also make a distinction between general and vocational education. This is done because we expect that workers who have attended general education will only have had informal training for a good performance in their present jobs. As stated earlier, we do not observe such informal training. The seven main categories are: primary education, LGSE, PVE, higher general secondary education/pre-university education (HGSE/PUE), IVE, HVE, and UE.

With this demarcation of main educational categories, we carried out four cluster analyses. The first two analyses are similar to the two already presented (i.e., a cluster analysis for the total working population aged 15-64 years old, and a cluster analysis restricted to the youngsters aged 15-29 years old), both based on 1994 data. In addition, analyses were carried out on the data set of EBB 1992 and a combination of EBB 1992 and EBB 1994, the latter for reasons of statistical reliability (larger average cell contents) and stability of the results. Table 4 presents an overview of the number of educational clusters resulting from the various analyses.

\section{Differences in the Results}

Comparing the results of the various cluster analyses presented is not a straightforward process. We therefore created an index that indicates the degree of relationship between two classifications. If slightly adjusted, the similarity index presented in the second section is suitable for this purpose. Let the index $S_{c, c^{\prime}}$ be defined as:

$$
S_{c, c^{\prime}}=\frac{\sum_{i}\left(\frac{p_{c, i}}{\sum_{j} p_{c, i}}\right)\left(\frac{p_{c^{\prime}, i}}{\sum_{i} p_{c^{\prime}, i}}\right)}{\sqrt{\sum_{i}\left(\frac{p_{c, i}}{\sum_{i} p_{c, i}}\right)^{2} \sum_{i}\left(\frac{p_{c^{\prime}, i}}{\sum_{i} p_{c^{\prime}, i}}\right)^{2}}}
$$


where $S_{c, c^{\prime}}$ is the similarity index of educational cluster $c$ with educational cluster $c^{\prime}$, and $p_{c, i}$ is the number of workers with educational background $i$ in educational cluster $c$.

The index $S_{c, c^{\prime}}$ is equal to 1 if both cluster $c$ and cluster $c^{\prime}$ consist of exactly the same educational categories, whereas it is equal to 0 if clusters $c$ and $c^{\prime}$ have no educational categories in common. With the aid of the indexes, we can test to what extent the results of two cluster analyses differ. Let $C$ and $C^{\prime}$ denote the results of two cluster analyses. The total similarity of the two classifications $C$ and $C^{\prime}$ can now be defined as:

$$
T S_{C, C^{\prime}}=\sum_{c \in C} \max _{c^{\prime} \in C^{\prime}} S_{c, c^{\prime}}
$$

or, in words, the index $T S$ is the sum of the highest similarities per educational cluster. If $C$ and $C^{\prime}$ distinguish the same educational clusters, then:

$$
\max S_{c, c^{\prime}}=1 \quad \forall c \in C, c^{\prime} \in C^{\prime}
$$

which implies that the maximum value of $T S_{C, C^{\prime}}$ is equal to the number of clusters distinguished in classification $C$ (NUMC). Therefore, we define:

$$
\alpha_{C, C^{\prime}}=\frac{T S_{C, C^{\prime}}}{N U M C}
$$

The index $\alpha$ will have a value between 0 and 1 . It is equal to 1 if and only if the two classifications $C$ and $C^{\prime}$ are perfectly identical. Table 5 presents the values of $\alpha$ for the comparison of the results of the three alternative cluster analyses with the results for the cluster analysis for 1994 data, restricted by educational main category. From these results, we may conclude that the results of the various cluster analyses are quite stable. For reasons of reliability of the data set, we opt for the analyses on the basis of the combined 1992 and 1994 data set, total work force. Obviously, the average cell content in this set is highest.

After carrying out the cluster analysis, the next step is to build the new educational classification on the basis of the results. As already indicated, doing requires that some additional criteria be taken into account. The first concerns the reliability of the data. As a minimum constraint, we use 5000 workers in each category. This implies that clusters with fewer than 5000 workers must be combined. As before, for doing this the similarity between educational clusters is

Table 5. Results of stability cluster analyses: 1994 data total workforce compared with three alternatives

\begin{tabular}{lcc}
\hline & $\begin{array}{c}\text { Alternative } \\
\text { age groups } \\
\text { (years) }\end{array}$ & $\alpha$ \\
\hline 1994 & $15-29$ & 0.84 \\
1992 & $15-64$ & 0.90 \\
1992 and 1994 & $15-64$ & 0.92 \\
\hline
\end{tabular}


taken as the criterion. After this combining of clusters, 120 types of education (of the 155 that resulted from the cluster analysis) are distinguished.

Subsequently, we checked the results on plausibility. This plausibility check is essentially based on the criterion of recognizability as formulated in the Introduction. This leads to several adjustments to the initially obtained results. Most adjustments are corrections of clustering of diverse educational categories due to overlapping 'secondary' occupations such as shop assistant, driver, etc. Furthermore, some distinctions were made in the cluster analysis, whereas in recent educational re-structuring educational categories are combined. For especially vocational guidance, it makes no sense to distinguish these categories in the classification.

After these changes made to the outcomes of the cluster analysis, the new educational classification consists of 113 categories (including several categories 'not earlier classified'). The Appendix provides a complete overview.

\section{Evaluation}

In the present paper, we have built an educational classification that is better suitable for analyses of the labour-market position of educational categories. The background of this classification is the economic theory on labour-market segmentation and the role of an individual's competencies on the substitution possibilities in the labour market. This results in a classification that gives a clearer picture of the real demarcations between educational categories in the labour market. As a result, the labour-market developments within the categories will be more homogeneous.

At the same time, the analyses carried out also shed more light on the substitution processes that take place in the labour market. In particular, workers with an educational background at IVE level frequently compete with workers who only have a PVE education, although it may be expected that IVE workers will upgrade their jobs compared with PVE-educated workers.

The new classification does not only have analytical, but also practical relevance. For example, the labour-market relatedness of education programmes will lead to a more realistic view of the occupation-specific importance of curricula that are developed, in particular in vocational education. The information that is provided can then be used to shift the occupational scope of these education programmes. For the authorities, the results may provide starting points for a review of the educational system. For example, it will probably be possible, particularly in education programmes with a high degree of labour-market relatedness, to achieve synergy effects. In the most extreme case, the curricula of different education programmes will be integrated fully in a single programme.

The new classification also provides useful information for study and job choices. The labour-market relatedness of education programmes shows, for example, that education programmes that formally have a different content but exhibit a high degree of labour-market relatedness can be used to acquire the same occupational position in the labour market, and that education programmes that at first seem similar in terms of content, but have only a limited labour-market relationship, will lead their graduates to entirely different occupational domains. For employers, this classification offers useful information in the case of labour shortages, which will enable them to recruit from different types of education that apparently generate related occupational competencies. 


\section{Hans Heijke et al.}

Unfortunately, the new classification does not solve all shortcomings of the older, more administrative one. This is mainly due to the fact that the old classification has to be (at a very detailed level) the input for the new one. An important drawback is that no distinction could be made between the various educational levels within the extensive IVE level. As the SOI classification does not distinguish between short IVE, long IVE and apprenticeships, these are also combined within one educational level in the classification presented here.

It is particularly unfortunate that the differentiation by educational level within the educational classification as a whole had to be introduced a priori and could not be deduced from the cluster procedure itself. It is theoretically argued, and empirically confirmed by studies using other data sets, that the initially observed substitution possibilities between educational categories of diverse levels can be due to temporary mismatch, upgrading within occupations, etc. Moreover, the dataset used does not provide insight into informal on-the-job training. The exclusion of such important factors results in unrealistic relationships between educational categories.

\section{Notes}

1. With respect to occupations, Sanderson (1987) makes a distinction between functional and administrative classifications.

2. Workers may, however, attain additional occupational skills by means of informal on-the-job training and work experience during their working career. Unfortunately, we have insufficient information on job tenures. To underpin this possible problem, we will later carry out an analysis that is restricted to youths, assuming that their mutual differences in working experience are less pronounced.

3. Similarly, we can derive the switching possibilities to other sectors of industry or combinations of occupations and industries.

4. Other techniques are based on the (squared) distance or the correlation between two categories (see, for example Lorr, 1983).

5. Earlier EBB surveys do not include information on educational categories at the five-digit SOI level.

6. The new ISCO 1988 was not yet available during the research.

7. Excluding educational categories with no respondents in EBB.

8. See CBS (1995) for the confidence intervals.

9. Two additional adjustments to the data set were necessary with respect to the occupational groupings distinguished. First, for our purposes, a major disadvantage of the three-digit occupational classification was that it made no distinction within the profession of teachers in secondary education. This implies that we should assume that perfect substitution can take place within this occupation, implying for instance that teachers of English are interchangeable with teachers of chemistry. As this is highly unrealistic, we divided the teaching professions into six main categories (general, arts, mathematics and natural sciences, medical, economic and social, and fine arts). This was done under the assumption that teachers belong to the category in which they were educated themselves. The second, similar disadvantage holds for the occupational group of doctor's and dentist's assistants. It may be expected that both doctor's assistants and dentist's assistants refer to specific craft markets with hardly any substitution possibilities. We have therefore divided the category of doctor's and dentist's assistants into two occupational categories in a similar way as for the teaching professions.

10. For instance, if HVE has the largest share of all educational levels within a cluster, the cluster is classified at HVE level.

11. de Grip et al. (1998), for example, found a positive relation between over-education and internal and upward mobility.

12. For the relevance of the latter, see the study by Heijke and Koeslag (1999) on the comparative labour-market position of economists who were educated at different levels.

13. We have to choose for this pragmatic solution, as testing the hypotheses of temporary misallocation and upgrading within occupations cannot be tested with the data set used. 


\section{References}

Becker, G. S. (1962) Investment in human capital: a theoretical analysis, fournal of Political Economy, 70, pp. 9-49.

Borghans, L. (1992) A histo-topographic map of Dutch university studies, $R O A-W-1992 / 5 E$ (Maastricht, Research Centre for Education and the Labour Market).

Borghans, L. \& Heijke, H. (1998) Flexibility and structure of the Dutch labour market, in: Heijke, H. \& Borghans, L. (Eds) Towards a Transparent Labour Market for Educational Decisions, pp. 119-150 (Aldershot, Ashgate).

CBS (1993) Standaard Beroepenclassificatie 1992 (Standard Occupational Classification 1992) (Voorburg/Heerlen, CBS).

Doeringer, P. B. \& Piore M. J. (1971) Internal Labor Markets and Manpower Analysis (Lexington, Heath).

Eijs, P. van (1993) The manpower requirements approach: background and methodology, $R O A$ RM-1993/3E (Maastricht, Research Centre for Education and the Labour Market).

Eijs, P. van (1994) Manpower forecasting in the Western world: the current state of the art, ROARM-1994/1E (Maastricht, Research Centre for Education and the Labour Market).

Eijs, P. van \& Heijke, H. (2000) Mismatch between occupation and education and the costs and benefits of job-related training, in: Heijke, H. \& Muysken, J. (Eds) Education and Training in a Knowledge-Based Economy, pp. 159-189 (London, Macmillan).

Grip, A. de \& Heijke, J. A. M. (1988) Labour market indicators: an inventory, $R O A-W-1988 / 1 E$ (Maastricht, Research Centre for Education and the Labour Market).

Grip, A. de, Groot, L. F. M. \& Heijke, J. A. M. (1987) Clustering occupational classes by educational structure, $R O A-W-1987 / 2 E$ (Maastricht, Research Centre for Education and the Labour Market).

Grip, A. de, Groot, L. F. M. \& Heijke, J. A. M. (1991) Defining occupational groupings by educational structure, Environment and Planning A, 23, pp. 59-85.

Grip, A. de, Heijke, H. \& Willems, E. (1998) Training and Mobility, The Netherlands' fournal of Social Sciences, 34, pp. 78-98.

Hartog, J. (1992) Capabilities, Allocation and Earnings (Boston, MA, Kluwer Academic Publishers).

Heijke, H. (Ed.) (1994) Forecasting the Labour Market by Occupation and Education (Boston, MA, Kluwer Academic Publishers).

Heijke, H. \& Koeslag, M. (1999) The labour-market position of university education and higher vocational education in economics and business administration: a comparison, Education Economics, 7, pp. 259-276.

Jovanovic, B. (1979) Job matching and the theory of turnover, fournal of Political Economy, 87, pp. 972-990.

Lorr, M. (1983) Cluster Analysis for Social Scientists (San Francisco, CA, Jossey-Bass).

Parnes, H. S. (1962) Forecasting Educational Needs for Economic and Social Development (Paris, OECD).

Sanderson, J. (1987) Defining functional occupational groupings, Environment and Planning A, 19, pp. $1199-1220$.

Schultz, T. W. (1961) Investment in human capital, American Economic Review, 51, pp. 1-17.

Sheldon, G. (1985) Die berufliche und geographische Flexibilität, Ph.D. Dissertation (Nürnberg, Institut für Arbeitsmarkt- und Berufsforschung des Bundesanstalt für Arbeit).

Thurow, L. C. (1975) Generating Inequality (New York, Macmillan).

Velden, R. K. W. van der \& Borghans, L. (1993) Competition on the labour market. An analysis of the position of types of training, ROA-RM-1993/5E (Maastricht, Research Centre for Education and the Labour Market).

Velden, R. van der \& Willems, E. (1994) The market position of occupations and types of education in the Netherlands, in: Heijke, H. (Ed.) Forecasting the Labour Market by Occupation and Education, pp. 137-163 (Boston, MA, Kluwer Academic Publishers). 


\section{Hans Heijke et al.}

\section{Appendix}

\section{Educational Classification}

Average number of workers of

\section{Primary education}

001 Primary education

00000-20199

500000

\section{PVE, LGSE}

$\begin{array}{ll} & \text { LGSE } \\ 002 & \text { LGSE } \\ & \text { PVE agriculture } \\ 003 & \text { PVE agriculture } \\ & \text { PVE technical trades } \\ & \text { PVE construction trades } \\ 004 & \text { PVE utilities installation } \\ 005 & \text { PVE mechanical trades } \\ 006 & \text { PVE micro-mechanical trades } \\ 007 & \text { PVE automobile trades } \\ 008 & \text { PVE electrical trades } \\ 009 & \text { PVE printing trades } \\ 010 & \text { PVE bakery trades } \\ 011 & \text { PVE hotel, catering and food } \\ 012 & \text { trades } \\ & \text { PVE transport } \\ 013 & \text { PVE other technical trades }\end{array}$

30100-30199

409000

30637, 32100-32999 76000

33610-33615, 33617-33629 135000

33616

9000

33631, 33633, $33638 \quad 131000$

33635

33641

33650-33659

33660-33669

33676

$33677,34430,38140,38340$

5000

49000

60000

7000

9000

35000

34100-34399 36000

33100-33199, 33642-33649,

37000

33670-33672, 33674-33675,

33678-33684, 33686-33699

PVE economics

015 PVE administration, commerce

33673, 33685, 36110-36699

131000 and textile

PVE community care

016 PVE community care
30667, 30671, 35100-35499, 37100-37199, 38100-38139, 38180-38199, 38330

184000

PVE public order and security

017 PVE security

39100-39399

10000

PVE other

$018 \quad$ PVE other

30690, 31100-31199, 31610, 38430, 38600-38699, 39800-39999

\section{IVE, HGSE}

\begin{tabular}{|c|c|c|c|}
\hline \multirow{2}{*}{019} & \multicolumn{3}{|l|}{ HGSE } \\
\hline & HGSE & $40100-40199$ & 306000 \\
\hline & \multicolumn{3}{|c|}{ IVE agriculture and the natural environment } \\
\hline 020 & $\begin{array}{l}\text { IVE arable farming and cattle } \\
\text { breeding }\end{array}$ & $\begin{array}{r}42110-42129,42150-42169 \\
42188-42199,42220-42999\end{array}$ & 112000 \\
\hline \multirow[t]{2}{*}{021} & IVE environment & $42130,42175,42183$ & 22000 \\
\hline & \multicolumn{3}{|l|}{ IVE Technology } \\
\hline 022 & IVE laboratory & $43100-43199,45210-45219$ & 19000 \\
\hline 023 & IVE construction & 43611-43615, 43618-43619, & 135000 \\
\hline
\end{tabular}




\begin{tabular}{|c|c|c|c|}
\hline Number & Educational type & SOI code & $\begin{array}{c}\text { Average } \\
\text { number of } \\
\text { workers of } \\
1992 \text { and } 1994\end{array}$ \\
\hline 024 & IVE civil engineering & $43623-43625,43823-43825$ & 21000 \\
\hline 025 & IVE utilities installation & 43616,43816 & 25000 \\
\hline 026 & $\begin{array}{l}\text { IVE mechanical engineering and } \\
\text { technology }\end{array}$ & $\begin{array}{l}\text { 42210, 43631, 43633, 43638, 43643, } \\
\text { 43647-43648, 43833, 43838, 43843, } \\
\text { 43847-43848, 44231, 44250-44299 }\end{array}$ & 140000 \\
\hline 027 & IVE micro-mechanical technology & $43635,43835,45280$ & 15000 \\
\hline 028 & IVE automobile technology & $43641,43649,43841$ & 62000 \\
\hline 029 & IVE aviation technology & 43645 & 6000 \\
\hline 030 & IVE operational technology & 43646 & 9000 \\
\hline 031 & IVE electrical technology & $43650-432659,43850-43859$ & 143000 \\
\hline 032 & IVE printing technology & $43660-43669,43867-43869$ & 39000 \\
\hline 033 & IVE process technologies & $\begin{array}{l}43674,43675,43678,43679,43874 \\
\quad 43875,43878,43879\end{array}$ & 20000 \\
\hline 034 & IVE bakery technology & 43676,43876 & 16000 \\
\hline 035 & $\begin{array}{l}\text { IVE food technology/meat } \\
\text { processing }\end{array}$ & 43677,43877 & 25000 \\
\hline 036 & IVE transport & $\begin{array}{l}40657,44100-44199,44210 \\
\quad 44238-44241,44248,44300-44999\end{array}$ & 46000 \\
\hline \multirow[t]{2}{*}{037} & IVE other technology & $\begin{array}{l}43671-43673,43682,43688-43699 \\
\quad 43888-43999\end{array}$ & 20000 \\
\hline & IVE services and health care & & \\
\hline 038 & $\begin{array}{l}\text { IVE doctor's, dentist's and } \\
\text { veterinary assistant }\end{array}$ & $45118,45138,45160$ & 18000 \\
\hline 039 & IVE pharmacist's assistant & 45220 & 16000 \\
\hline 040 & IVE nursing & 45120,45380 & 97000 \\
\hline 041 & IVE medical technology & $45230-45239$ & 6000 \\
\hline 042 & IVE social and cultural & $47100-47199$ & 55000 \\
\hline 043 & IVE community care & $\begin{array}{l}41610,45430,45480,48110-48129 \\
\quad 48180-48199,48320\end{array}$ & 199000 \\
\hline 044 & IVE hairdressers & 48130,48330 & 57000 \\
\hline 045 & IVE hotel and catering & 48140,48340 & 70000 \\
\hline \multirow[t]{2}{*}{046} & IVE physical therapy & $\begin{array}{l}40667,45140-45159,45161-45179 \\
\quad 45181-45199,45240-45249,45410 \\
45900\end{array}$ & 18000 \\
\hline & IVE economics & & \\
\hline 047 & IVE administration & $\begin{array}{l}46110,46133,46138,46141,46148 \\
46180-46199,46600-46629,46690\end{array}$ & 269000 \\
\hline 048 & IVE commerce & $\begin{array}{l}43617,43685,43817,43885,46143 \\
\quad 46150-46159,46280\end{array}$ & 281000 \\
\hline 049 & IVE secretarial & $45180,45310,46131$ & 93000 \\
\hline 050 & IVE tourism and recreation & 46142 & 15000 \\
\hline 051 & IVE business administration & $46120-46129,46220$ & 30000 \\
\hline 052 & IVE computer technology & 46135 & 28000 \\
\hline 053 & $\begin{array}{l}\text { IVE monetary, banking and } \\
\text { taxation }\end{array}$ & 46145,46630 & 36000 \\
\hline 054 & $\begin{array}{l}\text { IVE insurance } \\
\text { IVE public order and security }\end{array}$ & 46146 & 22000 \\
\hline 055 & $\begin{array}{l}\text { IVE public order and security } \\
\text { IVE other }\end{array}$ & $49100-49799$ & 80000 \\
\hline 056 & IVE other & $\begin{array}{l}\text { 40617-40656, 40658, 40670-40699, } \\
\quad 41110-41199,46240,48400-48699 \\
49800-49999\end{array}$ & 13000 \\
\hline
\end{tabular}




\begin{tabular}{|c|c|c|c|}
\hline Number & Educational type & SOI code & $\begin{array}{c}\text { Average } \\
\text { number of } \\
\text { workers of } \\
1992 \text { and } 1994\end{array}$ \\
\hline \multicolumn{4}{|l|}{ HVE } \\
\hline & \multicolumn{3}{|c|}{ HVE education, interpreter and translator } \\
\hline 057 & $\begin{array}{l}\text { HVE primary school teacher } \\
\text { training }\end{array}$ & $\begin{array}{l}40611,50611-50617,50690-50699 \\
\quad 60611-60617,60692\end{array}$ & 144000 \\
\hline 058 & HVE language teacher training & $\begin{array}{l}50620-50625,50628,50629 \\
\quad 60620-60625,60628,60629 \\
70621-70625,70628,70629\end{array}$ & 27000 \\
\hline 059 & HVE science teacher training & $\begin{array}{l}50630-50659,60630-60659 \\
70630-70635\end{array}$ & 33000 \\
\hline 060 & $\begin{array}{l}\text { HVE economics and social } \\
\text { science teacher training }\end{array}$ & $\begin{array}{l}50626,50627,50660-50666,57181 \\
\quad 60626,60627,60660-60666,70626 \\
\quad 70627,70660-70666\end{array}$ & 31000 \\
\hline 061 & $\begin{array}{l}\text { HVE physical education teacher } \\
\text { training }\end{array}$ & 50667,60667 & 15000 \\
\hline 062 & $\begin{array}{l}\text { HVE medical and care teacher } \\
\text { training }\end{array}$ & $50670-50679,60670-60679$ & 14000 \\
\hline 063 & HVE arts teacher training & $\begin{array}{l}50680-50689,60680-60689 \\
70680-70689\end{array}$ & 32000 \\
\hline \multirow[t]{2}{*}{064} & HVE interpreter and translator & $51100-51199$ & 8000 \\
\hline & \multicolumn{3}{|l|}{ HVE agriculture } \\
\hline 065 & $\begin{array}{l}\text { HVE arable farming and cattle } \\
\text { breeding }\end{array}$ & 52110,52158 & 6000 \\
\hline \multirow[t]{2}{*}{066} & $\begin{array}{l}\text { HVE environmental science and } \\
\text { food technology }\end{array}$ & $\begin{array}{l}52128-52130,52171-52299,52900 \\
\quad 53677,53678\end{array}$ & 13000 \\
\hline & \multicolumn{3}{|l|}{ HVE technology } \\
\hline 067 & HVE laboratory & $53140,53149,53160,55210,55220$ & 38000 \\
\hline 068 & HVE construction & $53610-53619,53810-53819$ & 19000 \\
\hline 069 & HVE civil engineering & $53620-53629,53820-53829$ & 16000 \\
\hline 070 & HVE mechanical engineering & $53631-53649,53830-53849$ & 31000 \\
\hline 071 & HVE electronic technology & $\begin{array}{l}53110-53139,53150,53170-53190, \\
53650-53651,53653-53655,53682, \\
53683\end{array}$ & 36000 \\
\hline 072 & HVE information technology & 53652,56135 & 37000 \\
\hline 073 & HVE chemical technology & $53670-53676$ & 7000 \\
\hline \multirow[t]{2}{*}{074} & HVE transport and logistics & $54100-54999$ & 28000 \\
\hline & \multicolumn{3}{|l|}{ HVE paramedical services } \\
\hline 075 & HVE nursing & 55120,55380 & 44000 \\
\hline 076 & HVE (physio)therapy & $\begin{array}{l}55140-55149,55151,55153,55180 \\
\quad 55238\end{array}$ & 36000 \\
\hline 077 & HVE nutrition & 55420,58180 & 5000 \\
\hline 078 & HVE radiology & $55241-55243$ & 7000 \\
\hline \multirow[t]{2}{*}{079} & HVE other paramedical services & $\begin{array}{l}55110-55119,55130-55133,55160 \\
55190-55199,55231,55248,55280 \\
55480\end{array}$ & 6000 \\
\hline & \multicolumn{3}{|l|}{ HVE economics } \\
\hline 080 & $\begin{array}{l}\text { HVE accounting and business } \\
\text { administration }\end{array}$ & $\begin{array}{l}56110,56133,56138,56210,56240 \\
\quad 56249,56630\end{array}$ & 54000 \\
\hline 081 & HVE commerce & $56143-56180$ & 40000 \\
\hline 082 & HVE tourism and recreation & 56142 & 8000 \\
\hline
\end{tabular}




\begin{tabular}{|c|c|c|c|}
\hline Number & Educational type & SOI code & $\begin{array}{c}\text { Average } \\
\text { number of } \\
\text { workers of } \\
1992 \text { and } 1994\end{array}$ \\
\hline 083 & HVE legal and fiscal & $56611-56629,56690$ & 22000 \\
\hline 084 & HVE secretarial & 55310,56131 & 38000 \\
\hline 085 & $\begin{array}{l}\text { HVE business administration } \\
\text { technology }\end{array}$ & $52310,52350,52380,56120,56220$ & 46000 \\
\hline & HVE social and cultural & & \\
\hline 086 & $\begin{array}{l}\text { HVE communication and } \\
\text { journalism }\end{array}$ & 56141,57120 & 11000 \\
\hline 087 & HVE social and welfare work & $\begin{array}{l}51610,57111,57115-57119 \\
\quad 57188-57199\end{array}$ & 65000 \\
\hline 088 & HVE personnel work & 57113 & 20000 \\
\hline 089 & HVE library and documentation & 57130 & 15000 \\
\hline 090 & $\begin{array}{l}\text { HVE other social and cultural } \\
\text { HVE fine arts }\end{array}$ & $57141,57143,57145-57165$ & 11000 \\
\hline 091 & $\begin{array}{l}\text { HVE performing and visual arts } \\
\text { HVE public order and safety }\end{array}$ & $58610-58640,58680-58699,68610$ & 45000 \\
\hline 092 & $\begin{array}{l}\text { HVE public order and safety } \\
\text { HVE other }\end{array}$ & $59100-59499$ & 10000 \\
\hline 093 & HVE other & $\begin{array}{c}53685-53699,53868,53885,53900 \\
56190-56199,58110-58125,58190 \\
58340,58900-58999,59900-59999\end{array}$ & 19000 \\
\hline \multicolumn{4}{|l|}{ UE } \\
\hline & $U E$ arts and theology & & \\
\hline 094 & UE arts & $61100-61199,71100-71199$ & 42000 \\
\hline \multirow[t]{2}{*}{095} & UE theology & 61610,71610 & 6000 \\
\hline & \multicolumn{3}{|c|}{ UE agriculture and environmental science } \\
\hline \multirow[t]{2}{*}{096} & $\begin{array}{l}\text { UE agriculture and } \\
\text { environmental science }\end{array}$ & $\begin{array}{l}62110-62130,62158,62170-62180 \\
62182-62189,62200-62999,72175\end{array}$ & 11000 \\
\hline & UE Technology & & \\
\hline 097 & $\begin{array}{l}\text { UE mathematics and natural } \\
\text { sciences }\end{array}$ & $\begin{array}{l}63110-63199,63631,63670-63688 \\
\quad 73110-73199,73674,73675\end{array}$ & 63000 \\
\hline 098 & UE Construction & $63613-63618,63818,73618$ & 11000 \\
\hline 099 & UE Civil engineering & $63623-63625,73623$ & 6000 \\
\hline 100 & UE mechanical engineering & $62181,63643-63649,73645-73648$ & 10000 \\
\hline 101 & UE electrical engineering & $\begin{array}{l}63650-63651,63653-63659,72181 \\
73650-73651,73653-73659\end{array}$ & 11000 \\
\hline 102 & UE Information technology & $63652,66135,73652,76135$ & 7000 \\
\hline & UE medical & & \\
\hline 103 & $\begin{array}{l}\text { UE veterinary and medical } \\
\text { sciences }\end{array}$ & $65111,65160,75111,75160$ & 44000 \\
\hline 104 & UE dentistry & 65131,75131 & 6000 \\
\hline \multirow[t]{2}{*}{105} & UE pharmacy & $65200-65299,75200-75299$ & 5000 \\
\hline & UE economics & & \\
\hline 106 & UE econom(etr)ics & $\begin{array}{l}66110,66141-66219,66221-66240 \\
\quad 76110,76141-76219\end{array}$ & 32000 \\
\hline 107 & UE management & $66120,66220,76120$ & 11000 \\
\hline 108 & UE accounting and fiscal science & $66133,66630,76133,76630$ & 15000 \\
\hline 109 & UE law and public administration & $\begin{array}{l}66118,66610-66629,66631-66699 \\
76118,76610-76629\end{array}$ & 50000 \\
\hline
\end{tabular}




\section{Hans Heijke et al.}

\begin{tabular}{|c|c|c|c|}
\hline Number & Educational type & SOI code & $\begin{array}{c}\text { Average } \\
\text { number of } \\
\text { workers of } \\
1992 \text { and } 1994\end{array}$ \\
\hline 110 & $\begin{array}{l}\text { UE social and cultural } \\
\text { UE social sciences }\end{array}$ & $\begin{array}{c}65148,65180-65199,67120,67130 \\
\quad 67141-67188,68110,68180,75148 \\
75151,75180,77130,77141-77188\end{array}$ & 75000 \\
\hline 111 & $\begin{array}{l}\text { UE other social and cultural } \\
\text { UE fine arts }\end{array}$ & $67110-67119,67190,77113$ & 11000 \\
\hline 112 & $\begin{array}{l}\text { UE fine arts } \\
\text { UE other }\end{array}$ & 68640 & - \\
\hline 113 & UE Other & $\begin{array}{l}63690,63900,65380,65480,65900 \\
\quad 68690,69150-69999\end{array}$ & - \\
\hline
\end{tabular}

Notes: All educational levels in this Appendix are defined as the following: PVE (Preparatory Vocational Education), LGST (Lower General Secondary Education), HGSE (Higher General Secondary Education), IVE (Intermediate Vocational Education), HVE (Higher Vocational Education), and UE (University Education). 
Copyright $\odot 2003$ EBSCO Publishing 